Quaternary International 474 Part B, Romagnoli, F., Nishiaki, Y., Rivals, F., Vaquero, M. (Eds.), "Multidisciplinary approaches in the definition of high-resolution events to interpret past human behaviour: a new challenge in archaeology", 168-181

\title{
Here and now or a previously planned strategy? Rethinking the concept of ramification for micro-production in expedient contexts: Implications for Neanderthal socio-economic behaviour.
}

Francesca Romagnoli ${ }^{\mathrm{a}}$, Bruno Gómez de Soler ${ }^{\mathrm{b}, \mathrm{c}}$, Amelia Bargallód ${ }^{\mathrm{d}}$, M. Gema Chacón ${ }^{\mathrm{b}, \mathrm{c}, \mathrm{e}}$, Manuel Vaquero $^{\text {b,c }}$

${ }^{a}$ Departamento de Prehistoria y Arqueología, Universidad Autónoma de Madrid, Ciudad Universitaria de Cantoblanco, 28049 Madrid, Spain.

${ }^{\mathrm{b}}$ IPHES - Institut Català de Paleoecologia Humana i Evolució Social, Campus Sescelades URV (Edifici W3), 43007 Tarragona, Spain.

${ }^{c}$ Area de Prehistoria, Universitat Rovira i Virgili (URV), Avinguda de Catalunya 35, 43002 Tarragona, Spain.

${ }^{\mathrm{d}}$ Institute of Archaeology, University College of London, Gordon Square 31-34, WC1H0PY London, U.K.

${ }^{\text {e }}$ Histoire Naturelle de l'Homme Préhistorique - HNHP - UMR 7194, (CNRS - MNHN - UPVD Sorbonne Université), 1 rue René Panhard, 75013 Paris \& Musée de l'Homme, 17 Place du Trocadéro, 75016 Paris, France

\footnotetext{
Abstract. Ramification is the term used to classify branched productive sequences in which a functional item (the flake) was exploited as a productive item (the core). This technological behaviour was present in Europe and the Levant beginning in the Lower and Early Middle Palaeolithic, but ramified productions were intensely developed in the Late Middle Palaeolithic. Traditionally, ramification has been interpreted as a well-structured behaviour, implying its integration into the provisioning strategies of past humans. This viewpoint has significant implications for the understanding of technological evolution in Neanderthals, suggesting specific cognitive and socio-economic capacities. Ramified procedures were characterised by high flexibility due to the versatile patterns of the core-on-flake and are described in the literature as corresponding to several different knapping concepts and technical procedures. This research aimed to describe the role of ramification in the Late Middle Palaeolithic. We analysed two assemblages from the Abric Romaní site (located in the north-east part of the Iberian Peninsula) characterised by informal, expedient technologies. The focus was on the spatial and temporal fragmentation of the ramified sequences based on the identification of single technical events. The reduction of the scale of analysis and the resulting implementation of temporal resolution of the stone tool assemblages in such expedient contexts allowed us to understand ramification from an innovative perspective, setting aside our bias toward well-defined productive methods associated with preconceived economic and mobility patterns. The results showed that ramification reflected a range of
} 
behaviours, implying a variety of planning proficiency, economic strategies and social interactions. This means that 'ramified production' is not meaningful unless is linked with a detailed description of human choices and an understanding of temporal and spatial relationships between knapping events. Furthermore, the results showed that, to approach behavioural issues, we as researchers must change our unitary vision of assemblages and enlarge the scope of categories to which we apply that vision.

Keywords. Middle Palaeolithic; core-on-flake; lithic technology; spatial analysis; refits; Abric Romaní.

\section{Introduction}

The concept of 'ramification' in the study of past technological behaviour was introduced by Bourguignon et al. (2004) to identify the process that allows the diversification of a production sequence into several phases in which flakes previously obtained are later exploited as cores. This means that the technical role of a flake changes from that of an object ready to be used (with or without retouch) and which possesses a functional edge and a prehensile portion to that of an object which serves as raw material stock for production and which possesses a specific volumetric construction suitable to be divided into tools. While during the last century, the categories 'tool' and 'core' were unambiguously distinct and each was related to a specific and complementary sphere of human behaviour, since the late 1990s, it has become clear that these classes of artefacts are not always easily distinguished (Newcomer and Hivernel-Guerre, 1974; Tixier and Turq, 1999; Bernard-Guelle and Porraz, 2001; Bourguignon and Turq, 2003; McPherron, 2007; Romagnoli, 2015).

Several studies have shown that the dual role of flakes used as cores was present in Europe and the Levant since the Lower and Early Middle Palaeolithic (e.g., Delagnes, 1993; Geneste and Plisson, 1996; Ashton, 2007; Assaf et al., 2015), but it seems that ramified productions where intensely developed starting in the European Late Middle Palaeolithic. They have been interpreted by some authors as a planned behaviour well integrated into provisioning strategies since the beginning of the reduction sequences (Bourguingon et al., 2004; Rios-Garaizar et al., 2015). The studies have traditionally focused on the final products issued from these branching exploitation strategies. They are recognisable because of the presence on their dorsal surface of a portion of the lower surface of the original flake used as a core (double ventral surface). They were short flakes, often microlithic, with a sharpened cutting edge. Researchers have usually highlighted the 'searched' characteristic of the ramified micro-production according to several aspects: the systematic production of small blanks in Middle Palaeolithic industries; the edge modification through retouch; the presence of use-wear traces on the functional edge of ramified blanks and on micro-flakes in general; the linked chain of detachments on the core-on-flake during the reduction sequence; and the relationship between ramification and distant raw material resources (Bourguingon et al., 2004; Rios-Garaizar, 2010, 2012; Claud et al., 2012; Villaverde et al., 2012; Lemorini et al., 2015; Rios-Garaizar et al, 2015). Neither these characteristics were mutually exclusive, nor were all present on the same assemblage.

The relevance of understanding ramification as a structured production process in the Late Middle Palaeolithic lies in the interpretation of the technological evolution of Neanderthals. It suggests not only changes in cognitive capacities, such as improved planning behaviour, but also an increasing 
complexity of activity organisation, including new tasks and social division of labour (RiosGaraizar et al, 2015; Mathias, 2016). Furthermore, several studies have linked ramified production to recycling (see: Barkai et al, 2015). However, there is no general consensus on this issue, and some studies have asserted the need for the identification of a spatial discontinuity between the core-on-flake sequence and the previous sequence from which the secondary production branched (Vaquero et al., 2015) or the presence of unambiguous evidence of sequential flaking, such as double patina and obsidian hydration band thicknesses, to associate the exploitation of cores-onflakes with recycling (Amick, 2007).

The flexibility of cores and flakes that results in the possibility of these artefacts having different technical roles at different times or even being multi-functional (this option cannot be excluded due to the difficulty, in many archaeological cases, of identifying the order and the possible temporal gap between sequential events) suggests that ramification implies a complex and dynamic pattern of production, use and discard events. This dynamicity engenders the ambiguity of classes and types of artefacts as universal and generally applied categories. This, in turn, implies that, as researchers, we must focus on the degree to which each artefact fits with each category and analyse in detail, on a case-by-case basis, the economic significance of human choices rather than use an analytical approach in which exclusive, immovable and rigid categories are used to describe and understand human behaviour. Only by changing the analytical approach to be more flexible it is possible to understand the variable patterns of cores-on-flakes as responses of Neanderthal groups to their physical and social environments (Hovers, 2007; Kuhn, 2007). Examples of this high degree of variability include the presence of structured ramified production processes on the Levantine Mousterian that were systematically applied to strictly locally available raw material (Goren-Inbar, 1988; Hovers, 1990); the systematic development of ramified sequences on distantly located resources in northern Iberia (Rios-Garaizar, 2010); and even the association between ramified sequences and independent debitage production of small tools.

It is the authors' opinion that a central aspect in the interpretation of branched production strategies is the mobility of the cores. Bourguignon et al. (2004) identified an underrepresentation of microproduction with respect to core-on-flake exploitation and suggested the mobility of part of the ramified sequence. The mobility of the cores-on-flakes has important implications in three main domains when approaching this issue from a behavioural perspective.

1) Planning and task organisation. There is a clear distinction to be made between the knapping proceedings in the same place where the tools are used and later transformed into cores-on-flakes, and the fragmentation of the ramification sequence in different places and at different times. These are two different processes in terms of planning. In the first case, the ramification could have simply been the response to knapping constraints or a quick way to obtain sharpened edges as a response to immediate needs. In this case, a low level of standardisation of procedures and products as well as of morpho-technical characteristics of cores-on-flakes could be expected given that the activity was quite extemporaneous. This opportunistic behaviour does not reflect the original idea proposed by Bourguignon et al. (2004) and supported by other colleagues that ramification was a planned behaviour. However, it is sometimes very difficult to identify the degree of 'opportunism' and of technical investment in archaeological contexts. Furthermore, an apparently opportunistic behaviour could be a strategy based on the provisioning of places as explained in the following part two. In this case, ramification would be a strategy related to human mobility (see below). The second picture paints a different scenario in which the location and timing of ramified products, and consequently of tasks for which the products are needed, had been 
foreseen and all or some of the flakes were transported as a stock of raw material. In this case, flakes would likely be quite big; they could be easily reduced in size during the following phases of production. Their use as tools before or during their exploitation as cores cannot be excluded a priori. This scenario must be distinguished by intra-site spatial discontinuity in ramified production, which can be associated with recycling (Vaquero et al., 2015). In the case of recycling, the displacement of the different phases of ramified production sequences in different intra-site areas may have resulted from responses to immediate needs and may reflect a specific human response in using the site as a raw material provisioning area. In each case, it is possible that the behaviour was systematic, suggesting a certain degree of planning in the stockpiling of the site for future visits.

2) Human mobility strategies. It may be intuitively proposed that ramification allows raw material productivity to be maximised but also that it minimises the costs of raw material provisioning. This consequence could have been advantageous in cases where exogenous resources were not available near the site and were characterised by specific chemical and physical features strictly linked with the function and the use-life of tools. At the same time, maximisation of productivity could have been beneficial in the case of time stress during tasks. It could also have been conditioned by the mobility of the human group and, thus, was not necessarily relegated to exogenous resources; this is supported by findings at archaeological sites (Hovers, 2007). Researchers specialising in stone tools often take it for granted that a search for abiotic resources was the main activity of past populations and, thus, do not take into account the possibility that this search could have been secondary to the search for edible and combustible resources. It follows that ramification could have been a response to the need, given high mobility, to have always available resources that were ready to be used for production, had a potentially long use-life, and were not too heavy to be transported (Bourguignon et al., 2006). However, ramification could also reflect a strategy based on the provisioning of places as is indicated by findings at sites of relatively long-term residence (Kuhn, 1995). In this case, the benefit of ramified production would have been the flexibility of the procedure, which would have enabled Neanderthals to easily create fresh, sharp edges with minimal processing required.

3) Informal versus formal knapping. Previous studies have pointed out the predetermined character of secondary, ramified Middle Palaeolithic final products (Delagnes, 1993;

Bourguignon and Turq, 2003; Bourguignon et al., 2004; Rios-Garaizar et al., 2015). In these cases, the authors described different knapping sequences carried out on a flake used as a core. Not only were the volumetric constraints of the core-on-flake different but also the technical procedures applied and the morpho-technical characteristics of the final products. Furthermore, in the literature on ramified productions, they were usually assimilated into micro-production in general. Micro-production in Middle Palaeolithic is well supported by findings and was clearly pointed out several years ago, though the significance of this peculiar toolkit implementation in the Late Pleistocene is still debated. However, neither core-on-flake and core debitage micro-productions were necessarily the consequence of a similar strategy, nor they have similar socio-economic implications. A detailed understanding of the complexity of ramified productions (meaning (i) a high level of control over the preparation of the volumetric constraints on the core-on-flake beyond the needed convexity of the ventral surface for production, (ii) a high level of technological investment and (iii) a high degree of standardisation of methods and final products) or, on the contrary, the expediency of these procedures could suggest different social dimensions in stone tool knapping and, most probably, in task organisation. 
The high flexibility of ramification and the need for researchers to use categories and classifications that are, by their very nature, rigid had generated 'macro-boxes' in which have been inserted apparently very different phenomena and behaviours. To analyse in detail not the general trend but the specific human strategies applied in each chronological, sedimentary and economic context is necessary to reduce the scope of analysis and study the assemblage at the scale of each technical event. The event is the focus of behavioural investigation and is the only parameter appropriate to approaching behavioural issues (Vaquero, 2008). The information extracted from the entire lithic assemblage of an archaeological layer or of a site will distort the interpretation by making it biased by the more visible (but not necessary more common) events and will mislead researchers' understanding of past behaviours because they will analyse activities and phenomena together that did not actually occur in the same moment at the same place (Bailey, 2007; Machado et al., 2015; Gabucio et al., 2016; Roda Gilabert et al., 2016; Romagnoli and Vaquero, 2016; Vaquero et al., 2015). Furthermore, it is of primary importance to be able to relate each ramification event to a specific constraint, economic strategy and mobility and to discern between possible different, independent events.

The aim of this research is to describe the role of ramification in the Late Middle Palaeolithic. We technologically analysed chert assemblages from two layers at the Abric Romaní site, which is dated to MIS 3 and characterised by informal production methods with low technical investment and poorly standardised knapping procedures. These industries are definable as expedient according to the low cost that was required for raw material procurement due to the lack of strong selection criteria and, in terms of production time, because of the application of informal knapping methods with poor control of the morpho-technical characteristics of flakes (Bleed, 1986; Torrence, 1989; Vaquero and Romagnoli, 2017). The focus of this research has been on the core-on-flake and on the spatial and temporal fragmentation between their 'ancestor' and 'descendant' production sequences to understand the technical status of these artefacts. The comprehension of ramification in expedient contexts allowed the evaluation of the degree of planning and the modalities of this behaviour from a different perspective than has been used up to now, avoiding the bias caused by the rigid definitions of production concepts like those of Quina and Levallois, in which the predetermination of products and specific economic and mobility models has been emphasised. To understand the socio-economic significance of the exploitation of core-on-flake production patterns, we have applied a high-resolution approach in which the temporal resolution of lithic assemblages has been enlarged to identify single technical events and to discuss them in the context of mobility, foraging strategies and spatial organisation of human activities.

\section{Materials and methods}

We have analysed chert assemblages from layers $\mathrm{M}$ and $\mathrm{L}$ at the Abric Romaní Middle Palaeolithic rockshelter. The site is located in the town of Capellades, approximately $50 \mathrm{~km}$ north-west of Barcelona (Fig. 1). The site is on a travertine cliff on the right bank of the Anoia river and is characterised by archaeological levels vertically well delimited and separated by sterile travertine platforms (Carbonell i Roura, 2012). The excavated stratigraphic sequence is approximately 20 meters thick and covers a timespan ranging from 70 to $40 \mathrm{ka}$ (Bischoff et al., 1988; Vaquero et al., 2013). A recent core sample has allowed the identification of at least 30 remaining meters of sediments, enlarging the chronology to $110 \mathrm{ka}$ (Sharp et al., 2016). Except for layer A, all of the archaeological layers testify to Middle Palaeolithic human frequentation. Layer Q is being excavated. From layer $\mathrm{H}$, the archaeological sequence has been investigated over more than $200 \mathrm{~m}^{2}$, 
and fieldwork methods have created a detailed spatial recording of almost the whole surface occupied by Neanderthals, with the 3D positioning in a Cartesian coordinate system of each lithic remain more than $1 \mathrm{~cm}$ long and faunal bone more than $2 \mathrm{~cm}$ long using a square grid of $1 \mathrm{~m}$. The site displays exceptional preservation of remains with very little impact of taphonomic agents (Cáceres et al., 2012; Gabucio et al., 2016, 2017; Romagnoli and Vaquero, 2016). The sedimentary processes have allowed the preservation of rich assemblages, also including wood remains and several hearths associated with butchery, production and sleeping areas (Vallverdú et al., 2010, 2012; Allué et al., 2016; Solé et al., 2013). Chert was the most exploited raw material along the whole sequence, comprising more than $70 \%$ of exploitation in each layer (with the exception of layer K, in which chert comprised less than $50 \%$ of the assemblage). Retouched elements were always less than $5 \%$ of the lithic assemblage in most layers.

\subsection{Layers $M$ and $L$}

The deposition of both layers occurred during the Dansgaard-Oeschger (D-O) cycles, which were characterised by abrupt and rapid climatic changes during MIS 3. In both layers, several hearths have been identified that were systematically fuelled by Pinus, mostly Pinus sylvestris; the pollen record showed, in association with Pinus, a predominance of Gramineae (Artemisia and Poaceae) in addition to meso- and thermophilic taxa related to climatic oscillation well attested within pollen zone 3 (Burjachs et al., 2012). The faunal assemblages were produced by Neanderthal hunting activities and were characterised by a high fragmentation rate due to human processing of carcasses (Fernández-Laso, 2010; Marín et al., 2017). In both layers, the main exploited macro-mammal resources were Cervus elaphus, Equus ferus and, to a much lesser extent, Bos primigenius (Chacón et al., 2014). The seasonality of human presence at the site has been estimated on the basis of hunting seasons, identified through tooth eruption on ungulates; such data suggest that layer $\mathrm{M}$ was occupied during autumn and early winter while layer L was occupied during spring (FernándezLaso et al., 2010). In layers $\mathrm{M}$ and $\mathrm{L}$, the chert assemblages showed a quite discrete spatial distribution, albeit with some differences both in the intensity of point patterns and in the management of intra-site occupational areas (Romagnoli and Vaquero, 2016; Fig. 1d,e).

The travertine platforms that delimit the top and the bottom of layer $\mathrm{M}$ have been dated at $51.8 \pm$ $1.4 \mathrm{ka} \mathrm{BP}$ and $54.6 \pm 2.3 \mathrm{ka} \mathrm{BP}$, respectively (U/Th dating; Bischoff et al., 1988). The layer yielded more than 4600 lithic remains greater than $1 \mathrm{~cm}$, and the chert assemblage included 3913 pieces $(84.1 \%)$. Limestone, quartz and schists comprised the rest of the abiotic resources exploited and were locally collected within a radius of less than $5 \mathrm{~km}$ from the site (Gómez de Soler, 2016). The most exploited chert formation was Sant Martí de Tous (SMT, 75.7\%), located approximately 15 $\mathrm{km}$ north-west from the site and characterised by blocks with variable degrees of homogeneity (Soto et al., 2014; Gómez de Soler, 2016). The constraints imposed by the heterogeneous grain-size and homogeneity of SMT chert blocks and the lack of strict criteria for block selection at the beginning of the chaînes opératoires were efficiently bypassed through the implementation of highly flexible knapping methods allowed by the application of a bifacial exploitation concept in which alternating bifacial and secant and bifacial and orthogonal removals were extracted from the same core (Romagnoli et al., 2016a). The most distant chert outcrops that had been exploited by Neanderthals at the site were in the Panadella formation (PAN) approximately $25 \mathrm{~km}$ north-west from the site. This resource was rarely exploited in layer M (2.0\%), was characterised by a high degree of homogeneity and was mainly fine-grained. The predominance of the exploitation of SMT chert was probably caused by the great abundance of this resource in the landscape, in addition to 
the mobility patterns of human groups (Gómez de Soler, 2016; Soto et al., 2017). Similar remarks can be made for the raw material data in layer $\mathrm{L}$.

The travertine platform above layer $\mathrm{L}$ has been dated at approximately $51.09 \pm 1.4 \mathrm{ka} \mathrm{BP}$ (the mean date of five U/Th dates ranging from $50.6 \pm 2$ to $53.0 \pm 0.8 \mathrm{ka} \mathrm{BP}$; Bischoff et al., 1988). The layer yielded 1091 lithic artefacts greater than $1 \mathrm{~cm} ; 960$ of these $(88 \%)$ were produced from chert while the rest of the assemblage was made of locally collected limestone, quartz, schist, granite and sandstone. (The analysis of the assemblage was completed for this research, after preliminary studies made by Gómez de Soler in 2009). Again, SMT outcrops were the most exploited: 557 pieces of a total of 595 analysed were from SMT outcrops (93.6\%). Materials were excluded if they were too burned, too patinated, or had a length less than $1 \mathrm{~cm}$ and, consequently, their petrographic attribution was not possible or reliable. The chert assemblage was characterised by recurrent, centripetal exploitation strategies aimed at obtaining flakes with a low level of core preparation and through alternating orthogonal and secant planes of detachment. PAN chert was only $6 \%$ of the petrographically analysed chert assemblage, corresponding to 36 pieces.

\subsection{Methods}

The chert assemblages from layers $\mathrm{M}$ and $\mathrm{L}$ were analysed with a high-resolution technological approach structured in stages. At the beginning, the entire assemblages were analysed with diacritical and morpho-technical approaches to reconstruct the logical organisation of knapping procedures through the identification of order and direction of removals on the cores and the other lithic elements (also including fragments and waste) and to infer the changes in the volumetric core construction during knapping. It it a procedure well established in stone tool analysis (Dauvois, 1976; Inizan et al., 1999). Later, the assemblages were analysed using the raw material unit (RMU) approach (Roebroeks, 1988; Larson and Kornfeld 1997); artefacts that were related to the exploitation of a single block or had been produced during a single knapping phase were isolated and divided into groups using macroscopic and microscopic features, including analysis of cortex, transition between cortex and matrix, inclusions and geodes, joint set, micropaleontology and morpho-sedimentary features. Furthermore, the technological analysis previously performed was used to infer the phases of productive sequences: the technical procedures applied during knapping left specific marks on flakes and cores and determined the morpho-technical characteristics of final products and waste related to a single chaîne opératoire and to a single phase of production. The assemblages have also been studied from a petrographic perspective, both macro- and microscopic. The internal and external characteristics as well as the textural and mineralogical compositions of rocks have been identified and described. The comparison with geological samples including thin sections, SEM and XRD, and $\mu$-XRD analysis allowed for the identification of chert formations. We have used the geological and petrographic lithoteque of the Institut Català de Paleoecologia Humana i Evolució Social related to the chert formations of the Ebro basin, the Prelittoral Range and the Prelittoral Depression (Soto et al., 2014; Gómez de Soler, 2016). At this level of analysis, it was possible to identify technological methods and typical products, identify the way in which raw material circulated in the landscape, read the technological costs, identify the knapping phases made at the site and relate each of them to a temporal scale in the organisation of technology. This is what may be called the intermediate temporal resolution. In the following analytical step, refits of the assemblages, including the pieces longer than $1 \mathrm{~cm}$, both fragments and complete elements regardless their attribution to product or waste categories, allowed the researchers to recognise each single technical event. The detailed identification of import, in-situ productive, recycling and export events and the understanding of their temporal relationships increased the temporal resolution of the analytical units reaching high resolution. Finally, intra-site spatial patterns 
were analysed. The high resolution was the analytical stage that allowed the undertaking of the behavioural inquiry and the retracing of the two-way analytical method dissecting the assemblage in single events and progressing from the events to human strategies and processes. The understanding of technical events and of their temporal relationships provides the basis for looking at the archaeological assemblages as a whole and discerning and discussing human strategies (meaning implying a choice and the reason for that choice) and socio-economic dynamics. In the paper, the term 'toolkit' refers to single elements that have been imported into the site as finished artefacts ready to be used and that were not related to in-situ knapping events. They have been identified through RMU analysis, refits and both qualitative and quantitative morpho-technical analysis.

\section{Results}

\subsection{Layer M}

The high-resolution database was composed of 2409 chert elements greater than $1 \mathrm{~cm}$ (Tab. 1) corresponding to $61.6 \%$ of the whole chert assemblage. These elements corresponded to 81 single elements representing portable toolkits, and 182 RMUs. Between them, 41 RMUs were made up of conjoined, fragmented artefacts, and 76 RMUs included refitted sequences. Refitted elements were $21.3 \%$ of the whole chert assemblage. Twenty-three cores-on-flakes were identified, and they all fitted in refitted sequences. None of them coincided with import events; they all were produced during in-situ knapping sequences and always, at the site, were further exploited as cores and finally abandoned. They were exploited in different ways. Some of them were used to obtain only a few flakes, their ventral surfaces exploited with no specific organisation of removals, while others were exploited during alternating recurrences, both uni- and bifacial, with a low degree of control of extracted flakes (as with the other knapping activities attested in this layer). The debitage could be organised along a limited portion of the core-on-flake with orthogonal or secant detachments or could be structured along the whole periphery of the core, determining a more typical discoid recurrence. In the case of recurrent centripetal debitage, the frequent production of flakes in a lateral portion of the core generated artefacts characterised by an asymmetric transversal section and a sharpened cutting edge used unretouched in opposition to a back. They were débordant flakes, pseudo-Levallois points, and to a lesser extent, backed knifes, usually not much elongated and with low morphological standardisation. All cores-on-flakes usually corresponded to short sequences. They were made on SMT chert, and the concerning blocks were usually characterised by low quality due to low homogeneity and to the frequent presence of geodes, which often impeded the regular propagation of the conchoidal fracture. This datum is in accordance with the general trend in the layer, where no specific selection criteria were put in place by the Neanderthals, and the exploited blocks usually showed very low quality. The cores-on-flakes showed variable sizes, with lengths between 20 and $66 \mathrm{~mm}$, widths between 17 and $72 \mathrm{~mm}$ and thicknesses between 7 and 27 mm (Fig. 2).

It was not uncommon to identify more than one core-on-flake within the same RMU; the 23 cores identified were classified within 10 RMUs. The technological analysis of refitted sequences showed that, due to the low quality of raw material, the result of percussion was frequently the production of a flake with irregular surfaces and variable morphology; this was a possible element that originated a branched production. RMUs flint- 073 and -075 were clear examples of this lack of planning in the organisation of ramified production. RMU flint-073 (Fig. 3) was a SMT chert block that was exploited with the recurrent centripetal method, alternating secant and orthogonal planes of 
detachment, adapting the organisation of removals to the morphology of the block. The refit was composed of 37 pieces, including the core. It was possible to reconstruct almost the entire block. Due to the lack of homogeneity of the raw material, most of the flakes were produced as fragments. Three flakes were further exploited as cores to obtain short artefacts with sharpened, unretouched edges. In one case, the branching productive process occurred once the flake was broken by a mesial, transversal fracture (Fig. 3b). RMU flint-075 was, again, a block exploited at the site. In the different refits corresponding to this RMU, 110 pieces have been assembled. The raw material was again characterised by very low homogeneity, large geodes, and abundant gypsum and salt ghosts (Fig. 4). These features and the presence of joint set determined the frequent running of fractures during knapping along the internal fissures. Instead of being thrown out, the debitage products thus obtained were systematically used as productive matrixes, adapting the organisation of removals to the volumetric constraints imposed by the raw material.

Due to the spatial discontinuity between the 'ancestor' sequence and the branched productions, it has been possible to frequently associate the exploitation of cores-on-flakes to recycling. In RMUs flint-073 and -075 , for example, part of the branched productive sequences were spatially segregated (Vaquero et al., 2015). In RMU flint-020, two cores-on-flakes were produced and exploited along a quite long sequence. The refit was constituted of 18 pieces. They were both exploited for very short ramified production: on one core, a single removal was obtained while the other produced two short, alternate flakes (Fig. 5a, b). The cores were found away from the extracted ramified flakes and from the main dispersion area of the RMU, which was located in the inner part of the rockshelter, near the back wall (Fig. 5).

\subsection{Layer $L$}

In layer $\mathrm{L}$, it has been possible to include 617 pieces within the high-resolution dataset, which is $64 \%$ of the whole chert assemblage (Tab. 1). It has been possible to identify 66 RMUs; 19 of them included refitted sequences, and 33 matched with the toolkit. A total of 164 pieces have been refitted, corresponding to $17 \%$ of the chert assemblage. Ten cores-on-flakes have been identified. Looking at the dimensions (Fig. 2), the biggest dimensions of cores-on-flakes could be noticed, especially concerning thickness as well as a reduced dimensional variability compared to layer M. Ramified final products showed similar patterns in the two layers with generally short dimensions but the highest length and thickness in layer L. All ramified sequences were developed on the SMT chert.

Ramified sequences showed a high degree of fragmentation. Three types of events have been identified: import, production and export. Usually, cores-on-flakes were introduced at the site ready to be used; the first phases of the 'ancestor' sequence were not attested there. This is, for example, the case of two cores (Refs: AR99-U52-38 and AR99-S43-156) that were exploited for alternating sequences along a peripheral portion of the flake, exploiting, in one case, the ventral natural convexity of the bulb and, in the other, the distal and lateral part of the flake (Fig. 6). The exploitation of the core-on-flake could have been characterised by a long life, including a complex dynamic of different functional performances. A clear case of complex patterns was found in refit 1 of RMU flint-001 (Fig. 7). A large double ventral flake was imported at the site, and its use-life was reconstructed in steps. (1) It was used as a core to produce several recurrent short flakes that were used and abandoned not far from the core. It is not possible to exclude the possibility of a previous (or contemporary) use of the core as a tool (Fig. 7a). (2) The core-on-flake was retouched on the left lateral edge, and its functional status changed again to that of a denticulate scraper (Fig. 7b). At 
present, no use-wear data are available on the retouched edge. The manufacturing of the proximal portion of the core-on-flake was made after step 1 and before step 2 and was probably aimed at regularising the transversal section of the large scraper. (3) Finally, the core was abandoned and was found modified by heat alterations. Only in one technical event was the use of a flake as a core applied along a knapping sequence made entirely at the site. This is the case of refit 10 in RMU flint-016 (Fig. 7c). The refit was constituted by eight elements and showed a knapping sequence in which a block was exploited and, along the productive sequence, a large flake was obtained. In turn, the flake was exploited as a core for a short recurrent series. The fragmentation of the chaînes opératoires included several export events. While it was not possible to identify lacking flakes as potential further cores, it was evident that there was a lack of ramified products related to cores-onflakes exploited at the site. The two cores described above were an example of this fragmentation and created a frequent picture in refitted assemblage.

In this layer, the analysis of spatial discontinuity in refitted sequences which included the whole refitted assemblage and not only ramified events showed several long-distance anthropic displacements, i.e., displacements more than five metres long (Vaquero, 2005; 2008; 2011). None of these displacements involved ramified cores or flakes.

\section{Discussion: how many processes and with which implications?}

Despite the fact that ramification in the studied layers was developed on the SMT chert formation located in a semi-local area (medium-low quality blocks), this technological behaviour was organised in a different way and matched with different processes. In layer M, the exploitation of cores-on-flakes was characterised by a continuum in-situ management of resources. On the contrary, in layer L, a spatial extra-site discontinuity has been recognised between the ramified and the 'ancestor' production sequences.

In layer M, cores-on-flakes were always produced during knapping sequences made at the rockshelter. Their exploitation was a response to functional constraints at the site. Previous studies have indicated that layer $\mathrm{M}$ was a campsite with domestic, multifunctional areas (Vaquero and Pastó, 2001; Fernández-Laso, 2010; Chacón et al., 2014; Gabucio et al., 2017; Marín et al., 2017). The undertaking of the entire process at the site and the exploitation of cores-on-flakes mainly for short series of extractions suggest that it was an expedient behaviour, with a low level of planning, used to respond to specific functional needs. Neanderthals took advantage of the quick production of short flakes with sharpened edges that were extracted with simple procedures. Thanks to its expedient features, almost any individual in the human group inhabiting the site could have performed this behaviour; it was advantageous in the case of participation in production and functional tasks by people with different degrees of knapping skills. In this respect, it is interesting to note that the overall technological organisation in this layer was based on the application of informal production methods that were highly adapted to the morphological constraints of the raw material, allowing resource diversification and reduction of technological costs (Chacón et al., 2013; Vaquero et al., 2015; Romagnoli et al., 2016a). The implementation of complexity in the Late Middle Palaeolithic is now well established due to the identification of symbolic behaviour, such as the use of ornaments and pigments (Bar-Yosef Mayer et al., 2009; Zilhão et al., 2010; Peresani et al., 2013; Soressi et al., 2013; Romandini et al., 2014); increased technological elaboration, including non-lithic adaptations (Carbonell and Castro-Curel, 1992; Mallye et al., 2012; Solé et al., 2013; Romagnoli et al., 2016b); and the use of mastics and multi-component tools (Villa et al., 2009; Pawlik and Thissen, 2011; Rots, 2015). The gender and age diversification of tasks was part 
of this increasing social complexity. Other studies have suggested that stone tool ramification may reflect this possibility (Rios-Garaizar et al, 2015; Mathias, 2016), which has also been supported through the analysis of activity-related dental wear (Estalrrich and Rosas, 2015). The results for layer M support the hypothesis that branching production was a collective response to social organisation of tasks but was not necessary related to the social division of activities carried out at the site. The generalised application of informal production concepts impeded the identification of different degrees of expertise and, consequently, of different social agents.

The use of the rockshelter for raw material stockpiling in this layer, identified with the frequent recycling of blanks, suggested that the human group had low mobility and occupied the site for relatively long-term stays. This scenario is coherent with the regular importation to the site of complete blocks due to the predictability of timing and location of activities and is comparable to the 'provisioning of place' defined by Kuhn (1995). This behaviour has been described in ethnographic contexts, often in the debate between the counterposed concepts of curation and expediency (Bamforth, 1986, 1991; Parry and Kelly, 1987; Nelson, 1991; Bamforth and Bleed, 1997 among others). The frequent association of the use of cores-on-flakes with recycling was part of the general mobility and social strategy of Neanderthals and of their spatial structuring of living space as shown by the spatial segregation of ramified sequences (Vaquero et al., 2015 and in this paper). The spatial segregation of ramified sequences suggests that ramification was not exactly a simple, opportunistic answer to immediate needs but rather a modality of raw material selection using the site for provisioning. Furthermore, we cannot exclude the use of flakes produced through ramified sequences for specific functional purposes, pointing at a functional organisation of living space. The structuring of living space was part of the behavioural evolution of the Middle Palaeolithic and suggests an increased complexity in social interactions (Alperson-Afil and Hovers, 2005). However, the socio-economic organisation of layer $M$ is a bit more complex, and the simple equation of 'intra-site spatial distribution of cores-on-flakes = differential use of space by social groups' could be misleading if the concept of time is not added to the examined parameters. Taphonomic and point pattern analysis have proven that the activity areas and domestic units identified in layer M were not occupied at the same time (Romagnoli and Vaquero, 2016). The longest-term occupation was located in the inner part of the rockshelter near the back wall while the central area, where recycled items where usually displaced for anthropic activities, was occupied during two different periods separated by a temporal hiatus attested by intermediate sterile sediments. Double ventral tools that were the results of ramified production have also been identified in the external part of the rockshelter in association with two single short occupational events related to the last phase of occupation at the site.

In layer $\mathrm{L}$ the flakes that where exploited as productive matrixes were systematically made outside the rockshelter, probably near the outcrops. In this layer, cores-on-flakes circulated as Neanderthals' portable provisioning. This behaviour can be assimilated into the individual provisioning described by Kuhn (1995). According to this author, in situations where uncertainty made it difficult to forecast the time schedule of extractive and maintenance tasks, people were obliged to undertake significant advance planning for possible future contingencies. As a consequence, they needed portable toolkits easily transported and versatile. The circulation of big flakes as part of the personal toolkit could have responded to this need and reflected a strong planning behaviour. Such behaviour can be expected in situation of patchy environments and/or climatic fluctuations, where highly mobile groups were faced with stochastic variation in resource availability, especially for foraging and, consequently, with a high risk of resource failure (Torrence, 1989; Andrefsky, 1991; Britt Bousman, 1993; Collard et al., 2005). Layers M and L 
were deposited during D-O 14. This cycle was characterised by a cold-dry climate and a pine forest with up to $33 \%$ warm, temperate taxa. Short climatic oscillations have been shown by fluctuation in the Pinus type and pollen taxa, suggesting alternating dry-cold and temperate-moist conditions within D-O 14 at Abric Romaní (Burjachs et al., 2012). Ramification as individual provisioning in layer L may be related to uncertain environments but at present the lack of changes in faunal exploitation and transport strategies limit the understanding of possible adaptive human responses. Furthermore, it is important to stress that human behaviour is influenced by many factors. External reasons, such as changes in plant-related availability that are expressed in pollen curves, must be taken into account with possible internal factors such as site function, demography and social dynamics.

The versatility of cores-on-flakes was evident because of the use of these items as tools as well as for short, expedient extraction of sharpened flakes (like the two cores presented in the paper) and for long, dynamic patterns of production, use, re-use and discard events. RMU flint-001 in layer L was a clear example of this long, complex history. The intra-site exploitation of a large doubleventral core-on-flake produced several short, sharpened flakes, each of which had both a convex distal cutting edge that was highly resistant due to the longitudinal trapezoidal section of the flakes and a concave proximal portion corresponding to previous removals. This volumetric construction was probably well adapted to the hand use of these tools (Baena Preysler et al., 2016) for precision tasks. After that, the core was manufactured as large retouched tool and, finally, abandoned. Further use-wear analysis could contribute to a better understanding of the role of tools not only for short ramified knapping events but also for a possible alternate use of the core-on-flake as an active tool. However, we must be aware that use-wear analysis probably will not allow us to go much deeper in dissecting the dynamic pattern of the use-life of cores-on-flakes. The removal of part of the core volume due to knapping may have taken away part of the previously used active edge and, consequently, made unreadable the traces related to the tool use phase of the core.

In layer L, a technological continuity has been identified in the application of informal productive concepts including recurrent centripetal methods (Chacón et al., 2007; 2014), although the strategy of toolkit transport changed and the degree of fragmentation of productive sequences increased. Furthermore, the intra-site anthropic displacement of flakes suggested, as in the underlying layer M, recycling behaviour and a differential temporal use between activity areas. Also, the structuration of the living floor was similar, with occupational units being characterised by at least one hearth and having the proxies for different activities (fauna rests and stone tools) and being similar to the domestic units attested in ethnographic contexts (Vaquero, 2005). However, the spatial pattern showed differences from layer $M$. The first residential episodes were located in the central part of the rockshelter and the last ones in the inner part, close to the back wall (Vaquero, 2008, 2011). These data imply that the rockshelter was still a residential campsite. However, the high fragmentation of the chaînes opératoires, the reduced number of items left at the site and the strongly discrete spatial distribution of remains indicate a short occupation (or rather repeated short occupations). Although faunal association does not show significant differences, the analysis of the hunting season also suggested short-term occupation(s) (Fernández-Laso, 2010; Fernández-Laso et al., 2010). Furthermore, the differences in spatial patterns suggested a different use of the site and probably different social dynamics.

A separate and complementary issue is how branched productions were integrated into more formal technological technocomplexes as is the case of layers $\mathrm{O}$ at Abric Romaní. This layer was characterised by a predominance of Levallois production, mostly recurrent centripetal production (Chacón et al., 2013; Bargalló, 2016; Picin and Carbonell, 2016). In this occupational phase, still 
attributed to MIS 3 and dated at approximately $55 \mathrm{ka} \mathrm{BP}$, the residential use of the site was more intense and/or took place during a longer time interval than that of the uppermost layers. This is visible in the formation of a complex palimpsest (Bargalló et al., 2015; Gabucio et al., 2016). Within the overlapping of several different events and the implementation of a greater behavioural variability, fragmented production sequences have been identified, with several independent import, production, use and discard events (Bargalló, 2016). A recent study showed that, along with other options, ramification was developed on SMT chert blocks outside the rockshelter and most probably near the outcrops during the first phases of the chaîne opératoires. This behaviour was aimed at reducing the original volume of blocks to discard their most inhomogeneous parts. It was a response to the need to obtain better-quality resources due to constraints imposed by the application of formal volumetric concepts and to maximise production once the core was preformed (Romagnoli et al., 2016). Further high-resolution studies must be performed to allow a better understanding of the evolution of branched productions along the sequence and in relation with the Middle Palaeolithic technological variability.

Not only the cores-on-flakes but also ramified flakes were displaced in the territory through import and export events. This is visible thanks to refits in layer L, where the flakes extracted from several imported cores-on-flakes have not been identified. At the same time, three artefacts extracted by a core-on-flake have been imported into the site as part of the mobile toolkit. The identification of the mobile status of this short production was only possible using a high-resolution approach and linking each remain to a specific technical event. The presence of both cores and products related to ramification processes and made by SMT chert resources could have otherwise biased the interpretation, suggesting the presence at the site of the whole chaîne opératoire. The functional role of ramified and Middle Palaeolithic micro-production in general is still debated. Use-wear analysis, still rare, suggests that short flakes were often used without previous configuration and were employed in butchery activities as well as in working with fresh hide, wood and herbaceous plants, with different functional performances (Geneste and Plisson, 1996; Barkai et al., 2010; Claud et al., 2012; Rios-Garaizar, 2012; Lazuén and González-Urquijo, 2015; Lemorini et al., 2015). Further functional studies are needed to determine if and how micro-debitage and ramified short productions were integrated and complementary processes. Furthermore, it is still to be investigated the possible differing functional status of micro-flakes between specialised and multifunctional tools and the length of their use-lives.

A final consideration regarding the socio-economic significance of the core-on-flake can be evaluate according to the mobile pattern of these artefacts. In the case of fragmented sequences, as attested in layer L, where a core-on-flake was a piece of personal gear, lithic production or, at least, ramified knapping could be interpreted as a non-social activity. This hypothesis is strengthened by the spatial distribution of ramified sequences, which were always clustered in this layer, and by the informal method applied to cores-on-flakes. These data suggest that in layer $\mathrm{L}$ the same individual was exploiting the cores ad hoc for functional constraints. That lithic production was an individual behaviour without corresponding social status has been shown in ethnographic contexts where raw material was a personal provisioning and was associated with few standardised productive methods (Sillitoe and Hardy, 2003; Shott and Sillitoe, 2005). However, the circulation of big blanks with versatile functional potential, because of their advantage in selecting portions of raw material with the highest homogeneity, could have implied a collective work near the outcrops in the first phases of the reduction sequences. Furthermore, the social status of these items in such organisation of technology cannot be discarded. In layer $\mathrm{M}$, the presence of entire productive sequences at the site and the application of the same informal concepts in knapping impede the inference of individual or 
collective behaviour in productive tasks. The understanding of social conducts in technical activities could be an interesting topic for future researchers, and the possible relationship between technical behaviour, including branching productions, resources availability, economic stress and human cooperation must be investigated further (Pereda et al., 2017).

\section{Conclusions}

Until now different and antithetical behaviours have been included in the definition of 'ramification'. In this study, we have shown that in the northeast part of the Iberian Peninsula ramification was conceived in different ways during MIS 3. It has been associated with different economic strategies, mobility and occupational patterns and linked with different types and degrees of planning according to contingencies and risk in foraging activities, social behaviour and site function. Results suggest that 'ramification' is inappropriate as a proxy either to describe a preconceived human behaviour or to infer specific socio-economic organisations. It would be like explain the production procedures simply using the concept 'knapping' or using 'butchery' to describe subsistence strategies. These concepts are too general to express the shared knowledge, the production aims, the environmental conditions and constraints, the foraging strategies, and the human mobility. Likewise, the use of the macro-definition 'ramified production' is not meaningful unless is linked with a detailed description of the specific choices deployed by humans at the different steps of the production process and an understanding of the temporal and spatial relationships between them. With this 'holistic' approach is possible to go beyond the dichotomy 'opportunistic' / planned, to evaluate the degree and modalities of planning, and to appreciate the technical, economic and social needs that underlying branched knapping. This study has highlighted how the application of high-resolution multidisciplinary analyses is highly suitable for approaching the study of ramification from a behavioural perspective. The implementation of multidisciplinary high-resolution studies in modern prehistory and in archaeology in general allows us to provide new answers and propose new hypotheses to old questions and concepts.

\section{Acknowledgements.}

This research was funded by the European Union's Horizon 2020 research and innovation programme under the Marie Sklodowska-Curie grant agreement No. 653667 (F.R.), HAR201676760-C3-1-P from the Spanish Ministry of Economy and Competitiveness (MINECO), and CERCA Programme/Generalitat de Catalunya. A.B. was supported by the European Union's Horizon 2020 research and innovation programme under the Marie Sklodowska-Curie Action grant agreement No. 702584. Research at Abric Romaní is supported by the Departament de Cultura of Generalitat de Catalunya, Diputació de Barcelona, Ajuntament de Capellades, and Arts Grafiques Romanya-Valls S.A. We are grateful to the editor, to Joseba Rios-Garaizar, and the anonymous reviewer for providing useful comments to improve the paper.

\section{Authors' contribution}

Conceived and designed the paper: F.R. Performed the technological analysis: F.R. Performed the lithic refits: F.R., A.B., M.G.C., M.V. Performed the spatial analysis: F.R., M.V. Performed the archaeopetrographic analysis: B.G.S. Written the paper: F.R. Results have been discussed by all the authors. 


\section{References}

Allué, E., Solé, A., Burguet-Coca, A., 2017. Fuel exploitation among Neanderthals based on the anthracological record from Abric Romaní (Capellades, NE Spain). Quaternary International 431, 6-15.

Alperson-Afil, N., Hovers, E., 2005. Differential use of space at the Neandertal site of Amud Cave, Israel. Eurasian Prehistory 3, 3-22.

Amick, D.S., 2007. Investigating the behavioral causes and archaeological effects of lithic recycling. In: McPherron, S. (Ed.), Tools versus cores: Alternatives approaches to stone tool analysis. Cambridge Scholars Publishing, Newcastle, UK, pp. 223-252.

Andrefsky, W.Jr., 1991. Inferring trends in prehistoric settlement behavior from lithic production technology in the Southern Plains. North American Archaeologist 12, 129-144.

Ashton, N., 2007. Flakes, cores, flexibility and obsession: situational behaviour in the British Lower Palaeolithic. In: McPherron, S. (Ed.), Tools versus cores: Alternatives approaches to stone tool analysis. Cambridge Scholars Publishing, Newcastle, UK, pp. 1-16.

Assaf, E., Parush, Y., Gopher, A., Barkai, R., 2015. Intra-site variability in lithic recycling at Qesem Cave, Israel. Quaternary International 361, 88-102.

Baena Preysler, J., Torres Navas, C., Pérez Díaz, S., Bustos-Pérez, G., Romagnoli, F., 2016. To grip or not to grip: an experimental approach for understanding the use of prehensile areas in mousterian tools. Boletín de Arqueología Experimental 11, 200-218.

https://revistas.uam.es/index.php/arqexp/article/view/7180.

Bailey, G., 2007. Time perspectives, palimpsests and the archaeology of time. Journal of Anthropological Archaeology 26, 198-223.

Bamforth, D.B., 1986. Technological efficiency and tool curation. American Antiquity 51, 38-50.

Bamforth, D.B., 1991. Technological organization and hunter-gatherer land use: a California example. American Antiquity 56, 216-234.

Bamforth, D.B., Bleed, P., 1997. Technology, flaked stone technology, and risk. In: Barton, M., Clark, G.A. (Eds.), Rediscovering Darwin: evolutionary theory in archaeological explanation. American Anthropological Association, Archaeological Papers N. 7. pp. 109-139.

Bargalló, A., 2016. Análisis tecnológico de los asentamientos Neandertales del nivel O: Abric Romaní (Barcelona, España). Publicia Publications, Saarbrücken.

Bargalló, A., Gabucio, M.J., Rivals, F., 2015. Puzzling out a palimpsest: testing an interdisciplinary study in level O of Abric Romaní. Quaternary International 417, 51-65.

Barkai, R., Lemorini, C., Gopher, A:, 2010. Palaeolithic cutlery 400 000-200 000 years ago: tiny meat-cutting tools from Qesem Cave, Israel. Antiquity 84.

Barkai, R., Lemorini, C., Vaquero, M., 2015. The origin of recycling: A Palaeolithic perspective. Quaternary International 361, 1-3.

Bar-Yosef Mayer, D.E., Vandermeersch, B., Bar-Yosef, O., 2009. Shells and ochre in Middle Paleolithic Qafzeh Cave, Israel: indications for modern behavior. Journal of Human Evolution 56, 307-314. 
Bernard-Guelle, S., Porraz, G., 2001. Amincissement et débitage sur éclat: définitions, interprétations et discussion à partir d'industries lithiques du Paléolithique moyen des Préalpes du nird françaises. Paléo 13, 53-72.

Bischoff, J.L., Julia, R., Mora, R., 1988. Uranium-series dating of the Mousterian occupation at the Abric Romani, Spain. Nature 332, 68-70.

Bleed, P., 1986. The optimal design of hunting weapons: maintainability or reliability. American Antiquity 51, 737-747.

Bourguignon, L., Delagnes, A., Meignen, L., 2006. Systèmes de production lithique, gestion des outillages et territoires au Paléolithique moyen: où se trouve la complexité? In: Astruc, L., Bon, F., Léa, V., Milcent, P.-Y., Philibert, S. (Eds.), Normes techniques et pratiques sociales: de la simplicité des outillages pré- et protohistoriques. APDCA, Antibes, pp. 75-86.

Bourguignon, L., Faivre, J.-P., Turq, A., 2004. Ramification des chaînes opératoires: une spécificité du Moustérien? Paléo 16, 37-48.

Bourguignon, L., Turq, A., 2003. Une chaîne opératoire de débitage Discoïde sur éclat du Moustérien à denticulés aquitain: les examples de Champs de Bossuet et de Combe-Grenal c.14. In: Peresani, M. (Ed.), Discoid lithic technology: Advances and implications. BAR International Series 1120, pp. 131-152.

Britt Bousman, C., 1993. Hunter-gatherer adaptations, economic risk and tool design. Lithic Technology 18, 59-86.

Burjachs, F., Lopez-Garcia, J.M., Allue, E., Blain, H.-A., Rivals, F., Bennàsar, M., Expósito, I., 2012. Palaeoecology of Neanderthals during Dansgaard-Oeschger cycles in northeastern Iberia (Abric Romani): from regional to global scale. Quaternary International 247, 26-37.

Cáceres, I., Bennàsar, M., Huguet, R., Rosell, J., Saladié, P., Fernández-Laso, M.C., Gabucio, M.J., Ibáñez, N., Martín. P., Muñoz, L., Rodríguez-Hidalgo, A., 2012. Taphonomy of level J of Abric Romaní. In: Carbonell i Roura, E. (Ed.), High resolution archaeology and Neanderthal behaviour. Time and space in Level J of Abric Romaní (Capellades, Spain). Springer Netherlands, pp. 159187.

Carbonell i Roura, E. (Ed.), 2012. High resolution archaeology and Neanderthal behaviour. Time and space in Level J of Abric Romaní (Capellades, Spain). Vertebrate Paleobiology and Paleoanthropology Series. Springer Netherlands.

Carbonell, E., Castro-Curel, Z., 1992. Palaeolithic wooden artefacts from the Abric Romaní (Capellades, Barcelona, Spain). Journal of Archaeological Science 19, 707-719.

Chacón, M.G., Bargalló, A., Gómez de Soler, B., Picin, A., Vaquero, M., Carbonell, E., 2013. Continuity or discontinuity of Neanderthal technological behaviours during MIS 3: level M and level O of the Abric Romaní site (Capellades, Spain). In: Pastoors, A., Auffermann, B. (Eds.), Pleistocene foragers on the Iberian Peninsula: their culture and environment. Festschrift in honour of Gerd-Christian Weniger for his sixtieth birthday. Wissenschaftliche Schriften des Neanderthal Museum Vol. 7, Mettman, pp. 55-84.

Chacón, M.G., Fernández-Laso, M.C., García-Antón, M.D., Allué, E., 2007. Level K and L from Abric Romaní (Barcelona, Spain): procurement resources and territory management in shorts occupations during the Middle Palaeolithic. In: Arzarello, M., Moigne, A.-M., Moncel, M.-H., Peretto, C. (Eds.), 
Aires d'approvisionnement en matières premières et aires d'approvisionnement en ressources alimentaires. BAR International Series 1725, pp. 187-197.

Chacón, M.G., Fernández-Laso, M.C., Rivals, F., 2014. Comportements des populations néandertaliennes pendant le MIS 3 à l'Abric Romaní: les niveaux K, L et M. Variabilité ou continuité? In: Jaubert, J., Fourment, N., Depaepe, P. (Eds.), Transitions, ruptures et continuité en Préhistoire, volume 2 Paléolithique et Mésolithique. Société préhistorique française, Paris, pp. 207228.

Claud, E., Soressi, M., Jaubert, J., Hublin, J.J., 2012. Étude tracéologique de l'outillage moustérien de type Quina du bonebed de Chez-Pinaud à Jonzac (Charente-Maritime). Nouveaux éléments en faveur d'un site de boucherie et de traitement des peaux. Gallia Préhistoire 54, 3-32.

Collard, M., Kemery, M., Banks, S., 2005. Causes of toolkit variation among hunter-gatherers: a test of four competing hypotheses. Canadian Journal of Archaeology 29, 1-19.

Dauvois, N., 1976. Précis de dessin dynamique et structural des industries lithiques préhistoriques. Fanlac, Perigueux.

Delagnes, A., 1993. Un mode de production inédit au Paléolithicuqe moyen dans l'industrie du niveau 6e du Pucheuil (Seine Maritime). Paléo 5, 111-120.

Estalrrich, A., Rosas, A., 2015. Division of labor by sex and age in Neanderthals: an approach through the study of activity-related dental wear. Journal of Human Evolution 80, 51-63.

Fernández-Laso, M.C., 2010. Remontajes de restos faunísticos y relaciones entre áreas domésticas en los niveles K, L y M del Abric Romaní (Capellades, Barcelona, España). PhD dissertation, Universitat Rovira i Virgili, Tarragona.

Fernández-Laso, M.C., Rivals, F., Rosell, J., 2010. Intra-site changes in seasonality and their consequences on the faunal assemblages from Abric Romani (Middle Paleolithic, Spain).

Quaternaire 21, 155-163.

Gabucio, M.J., Cáceres, I., Rivals, F., Barcaggó, A., Rosell, J., Saladié, P., Vallverdú, J., Vaquero, M., Carbonell, E., 2016. Unravelling a Neanderthal palimpsest from a zooarchaeological and taphonomic perspective. Archaeological and Anthropological Sciences, doi: 10.1007/s12520-0160343-y.

Gabucio, M.J., Fernández-Laso, M.C., Rosell, J., 2017. Turning a rock shelter into a home. Neanderthal use of space in Abric Romaní lavels M and O. Historical Biology, doi: 10.1080/08912963.2017.1340470.

Geneste, J.M., Plisson, H., 1996. Production et utilisation de l'outillage lithique dans le Moustérien du Sud-ouest de la France: les Tares à Sourzac, vallée de l'Isle, Dordogne. Quaternaria Nova 6, 343-368.

Gómez de Soler, B., 2009. Àrees de captació, tecnologia lítica i estratègies d'aprovisionament de roques silicies em el nivell L de l'Abric Romaní (Capellades, Barcelona). Quaderns de Prehistòria Catalana, 17, 11-56.

Gómez de Soler, B., 2016. Procedencia del aprovisionamiento lítico durante el Paleolítico medio en el yacimiento del Abric Romaní (Capellades, Barcelona). Niveles M, Oa y P. PhD dissertation, Universitat Rovira i Virgili, Tarragona. 
Goren-Inbar, N., 1988. Too small to be true? Reevaluation of cores on flakes in Levantine Mousterian assemblages. Lithic Technology 17, 37-44.

Hovers, E., 1990. The exploitation of raw material at the Mousterian site of Quneitra. In: GorenInbar, N. (Ed.), Quneitra: a Mousterian site on the Golan Heights. Qedem 31, Publications of the Institute of Archaeology, Jerusalem, pp. 150-167.

Hovers, E., 2007. The Many faces of cores-on-flakes: A perspective from the Levantine Mousterian. In: McPherron, S. (Ed.), Tools versus cores: Alternatives approaches to stone tool analysis. Cambridge Scholars Publishing, Newcastle, UK, pp. 42-74.

Inizan, M.L., Reduron-Ballinger, M., Roche, H., Tixier, J., 1999. Technology and terminology of knapped stone. CREP, Nanterre.

Kuhn, S.L., 1995. Mousterian lithic technology. An ecological perspective. Princeton University Press, Princeton.

Kuhn, S.L., 2007. Cores, tools, and the priorities of lithic analysis. In: McPherron, S. (Ed.), Tools versus cores: Alternatives approaches to stone tool analysis. Cambridge Scholars Publishing, Newcastle, UK, pp. 265-276.

Larson, M.L., Kornfeld, M., 1997. Chipped stone nodules: theory, method, and examples. Lithic Technology 22, 4-18.

Lazuén, T., González-Urquijo, J., 2015. Recycling in the Early Middle Palaeolithic: the role of resharpening flakes assessed through techno-functional analysis. Quaternary International 361, 229237.

Lemorini, C., Vanditti, F., Assaf, E., Parush, Y., Barkai, R., Gopher, A., 2015. The function of recycled lithic items al late Lower Paleolithic Qesem Cave, Israel: an overview of the use-wear data. Quaternary International 361, 103-112.

Machado, J., Molina, F.J., Hernández, C.M., Tarriño, A., Galván, B., 2016. Using lithic assemblage formation to approach Middle Palaeolithic settlement dynamics: El Salt stratigraphic Unit X (Alicante, Spain). Archaeological and Anthropological Sciences, doi: 10.1007/s12520-016-0318-z.

Mallye, J.B., Thiébaut, C., Mourre, V., Costamagno, S., Claud, E., Weisbecker, P., 2012. The Mousterian bone retouchers of Noisetier Cave: experimentation and identification of marks. Journal of Archaeological Science 39, 1131-1142.

Marín, J., Saladié, P, Rodríguez-Hidalgo, A., Carbonell, E., 2017. Ungulate carcass transport strategies at the Middle Palaeolithic site of Abric Romaní (Capellades, Spain). Comptes Rendus Palevol 16, 103-121.

Mathias, C., 2016. After the Lower Palaeolithic: Lithic ramification in the early Middle Palaeolithic of Orgnac 3, layer 2 (Ardèche, France). Quaternary International 411, 193-201.

McPherron, S. (Ed.), 2007. Tools versus cores: Alternatives approaches to stone tool analysis. Cambridge Scholars Publishing, Newcastle, UK.

Nelson, M.C., 1991. The study of technological organization. Archaeological Method and Theory 3, 57100.

Newcomer, M.H., Hivernel-Guerre, F., 1974. Nucléus sur éclat: technologie et utilisation par différentes cultures préhistoriques. Bulletin de la Société préhistorique française 71, 119-127. 
Parry, W.J., Kelly, R.L., 1987. Expedient core technology and sedentism. In: Johnson, J.K., Morrow, C.A. (Eds.), The organization of core technology. Westview Press, Boulder, Colorado, pp. 285-304.

Pawlik, A.F., Thissen, J.P., 2011. Hafted armatures and multi-component tool design at the Micoquian site of Inden-Altdorf, Germany. Journal of Archaeological Science 38, 1699-1708.

Pereda, M., Zurro, D., Santos, J.I., Briz i Godino, I., Álvarez, M., Caro, J., Galán, J.M., 2017. Emergence and evolution of cooperation under resource pressure. Scientific Reports 7, 45574.

Peresani, M., Vanhaeren, M., Quaggiotto, E., Queffelec, A., d'Errico, F., 2013. An ochered fossil marine shell from the Mousterian of Fumane cave, Italy. PLos ONE 8, e68572.

Picin, A., Carbonell, E., 2016. Neanderthal mobility and technological change in the northeastern of the Iberian Peninsula: the patterns of chert exploitation at the Abric Romaní rock-shelter. Comptes Rendus Palevol, 15, 581-594.

Rios-Garaizar, J., 2010. Organización económica de las sociedades Neandertales: el caso del nivel VII de Amalda (Zestoa, Gipuzkoa). Zephyrus ZXV, 15-37.

Rios-Garaizar, J., 2012. Industria lítica y sociedad en la transición del Paleolítico Medio al Superior en torno al Golfo de Bizkaia. PUbliCan Ediciones de la Universidad de Cantabria, Santander.

Rios-Garaizar, J., Eixea, A., Villaverde, V., 2015. Ramification of lithic production and the search of small tools in Iberian Peninsula Middle Paleolithic. Quaternary International 361, 188-199.

Roda Gilabert, X., Martínez-Moreno, J., Mora Torcal, R., 2016. Ground stone tools and spatial organisation at the Mesolithic site of Font del Ros (southeastern Pre-Pyrenees, Spain). Journal of Archaeological Science: Reports 5, 209-224.

Roebroeks, W., 1988. From find scatters to early hominid behaviour. A study of Middle Palaeolithic riverside settlements at Maastricht-belvedere (Netherlands). Analecta Praehistorica Leidensia 21, University of Leiden, Leiden.

Romagnoli, F., 2015. A second life: recycling production waste during the Middle Palaeolithic in layer L at Grotta del Cavallo (Lecce, Southeast Italy). Quaternary International 361, 200-211.

Romagnoli, F., Baena, J., Sarti, L., 2016b. Neanderthal retouched shell tools and Quina economic and technical strategies: an integrated behaviour. Quaternary International 407, 29-44.

Romagnoli, F., Bargalló, A., Chacón, M.G., Gómez de Soler, B., Vaquero, M., 2016a. Testing a hypothesis about the importance of the quality of raw material on technological changes at Abric Romaní (Capellades, Spain): some considerations using a high-resolution techno-economic perspective. Journal of Lithic Studies 3 (2), doi: 10.2218/jls.v3i2.1443.

Romagnoli, F., Vaquero, M., 2016. Quantitative stone tools intra-site point and orientation patterns of a Middle Palaeolithic living floor: A GIS multi-scalar spatial and temporal approach. Quartär 63, 47-60.

Romandini, M., Peresani, M., Laroulandie, V., Metz, L., Pastoors, A., Vaquero, M., Slimak, L., 2014. Convergent evidence of eagle talons used by late Neanderthals in Europe: a further assessment on Symbolism. PLos ONE 9, e101278. 
Rots, V, 2015. Hafting and site function in the European Middle Palaeolithic. In: Conard, N.J., Delagnes, A. (Eds.), Settlements dynamics of the Middle Palaeolithic and Middle Stone Age, volume IV. Tübingen Publications in Prehistory, Kerns Verlag, Tübingen, pp. 383-410.

Sharp, W.D., Mertz-Kraus, R., Vallverdú, J., Vaquero, M., Burjachs, F., Carbonell, E., Bishoff, J.L., 2016. Archaeological deposits at Abric Romaní extend to $110 \mathrm{ka}$ : U-series dating of a newly cored, 30 meter-thick section. Journal of Archaeological Science: Reports 5, 400-406.

Shott, M.J., Sillitoe, P., 2005. Use life and curation in New Guinea experimental used flakes. Journal of Archaeological Science 32, 653-663.

Sillitoe, P., Hardy, K., 2003. Living lithics: ethnoarchaeology in Highland Papua New Guines. Antiquity 77, 555-566.

Solé, A., Allué, E., Carbonell, E., 2013. Heart-related wood remains from Abric Romaní layer M (Capellades, Spain). Journal of Anthropological Research 69, 535-559.

Soressi, M., McPherron, S.P., Lenoir, M., Dogandzič, T., Goldberg, P., Jacobs, Z., Maigrot, Y., Martisius, N.L., Miller, C.E., Rendu, W., Richards, M., Skinner, M.M., Steele, T.E., Talamo, S., Texier, J.-P., 2013. Neandertals made the first specialized bone tools in Europe. Proceedings of the National Academy of Sciences 110, 14186-14190.

Soto, M., Gómez de Soler, B., Vallverdú, J., 2017. The chert abundance ratio (CAR): a new parameter for interpreting Palaeolithic raw material procurement. Archaeological and Anthropological Sciences, doi: 10.1007/s12520-017-0516-3.

Soto, M., Gómez de Soler, B., Vallverdú, J., Vaquero, M., 2014. Potential siliceous sources during Prehistory: Results of prospecting in the East margin of the Ebro Basin (NE Iberian Peninsula). Journal of Lithic Studies 1, 293-318.

Tixier, J., Turq, A., 1999. Kombewa et alii, Paléo 11, 135-143.

Torrence, R. (Ed.), 1989. Time, energy and stone tools. Cambridge University Press, Cambridge.

Vallverdú, J., Alonso, S., Bargalló, A., Bartrolí, R., Campeny, G., Carrancho, A., Expósito, I., Fontanals, M., Gabucio, J., Gómez, B., Prats, J.M., Sañudo, P., Solé, A., Vilalta, J., Carbonell, E., 2012. Combustion structures of archaeological level $O$ and mousterian activity areas with use of fire at the Abric Romaní rockshelter (NE Iberian Peninsula). Quaternary International 247, 313-324.

Vallverdú, J., Vaquero, M., Cáceres, I., Allué, E., Rosell, J., Saladié, P., Chacón, G., Ollé, A., Canals, A., Sala, R., Courty, M.A., Carbonell, E., 2010. Sleeping activity area within the site structure of archaic human groups. Evidence from Abric Romaní Level N combustion activity areas. Current Anthropology 51, 137-145.

Vaquero, M., 2005. Les stratégies de transport d'outils dans un contexte résidentiel: un exemple du Paléolithique moyen. In: Vialou, D., Renault-Miskovsky, J., Patou-Mathis, M. (Eds.), Comportements des hommes du Paléolithique moyen et supérieur en Europe: territoires et milieux. ERAUL, 111, Liège, pp. 121-132.

Vaquero, M., 2008. The history of stones: behavioural inferences and temporal resolution of an archaeological assemblage from the Middle Palaeolithic. Journal of Archaeological Science 35, 3178-3185. 
Vaquero, M., 2008. The history of stones: behavioural inferences and temporal resolution of an archaeological assemblage from the Middle Palaeolithic. Journal of Archaeological Science 35, 3178-3185.

Vaquero, M., 2011. New perspectives on recycling of lithic resources using refitting and spatial data. Quartär 58, 113-130.

Vaquero, M., Allué, E., Bischoff, J.L., Burjachs, F., Vallverdú Poch, J., 2013. Environmental, depositional, and cultural changes in the Upper Pleistocene and Early Holocene: the Cinglera del Capelló sequence (Capellades, Spain). Quaternaire 24, 49-64.

Vaquero, M., Bargalló, A., Chacón, M.G., Romagnoli, F., Sañudo, P., 2015. Lithic recycling in a Middle Paleolithic expedient context: Evidence from the Abric Romaní (Capellades, Spain). Quaternary International 361, 212-228.

Vaquero, M., Pastó, I., 2001. The definition of spatial units in Middle Palaeolithic sites: the hearthrelated assemblages. Journal of Archaeological Science 28, 1209-1220.

Vaquero, M., Romagnoli, F., 2017. Searching for lazy people: the significance of expedient behavior in the interpretation of Paleolithic assemblages. Journal of Archaeological Method and Theory, doi: 10.1007/s10816-017-9339-x.

Villa, P., Boscato, P., Ranaldo, F., Ronchitelli, A., 2009. Stone tools for the hunt: points with impact scars from a Middle Palaeolithic site in southern Italy. Journal of Archaeological Science 36, 850-859.

Villaverde, V., Eixea, A., Rios, J., Zilhão, J., 2012. Importancia y valoración de la producción microlevallois en los niveles II y III del Abrigo de la Quebrada (Chelva, Valencia). Zephyrus LXX, 1332.

Zilhão, J., Angelucci, D.E., Badal-García, E., d'Errico, F., Daniel, F., Dayet, L.,Douka, K., Higham, T.F.G., Martínez-Sánchez, M.J., Montes-Bernárdez, R., Murcia-Mascarós, S., Pérez-Sirvent, C., Roldán-García, C., Vanhaeren, M., Villaverde, V., Wood, R., Zapata, J., 2010. Symbolic use of marine shells and mineral pigments by Iberian Neandertals. Proceedings of the National Academy of Sciences 107, 1023-1028. 
Figure 1 - a. Geographical localisation of Abric Romaní rockshelter; b. Image of the site during excavation of layer M; c. Synthetic lithostratigraphic column; d. Spatial distribution of chert lithic assemblage in layer M; e. Spatial distribution of chert lithic assemblage in layer L. In the distribution maps hearths are drown in black; scale bar is 5 meters. Legend for the lithological column: 1. Red sands; 2. Carbonatic sands; 3. Filiform travertines; 4. Tubular travertines; 5. Carbonatic slabs; 6. Oncolithic gravels; 7. Travertine blocks.
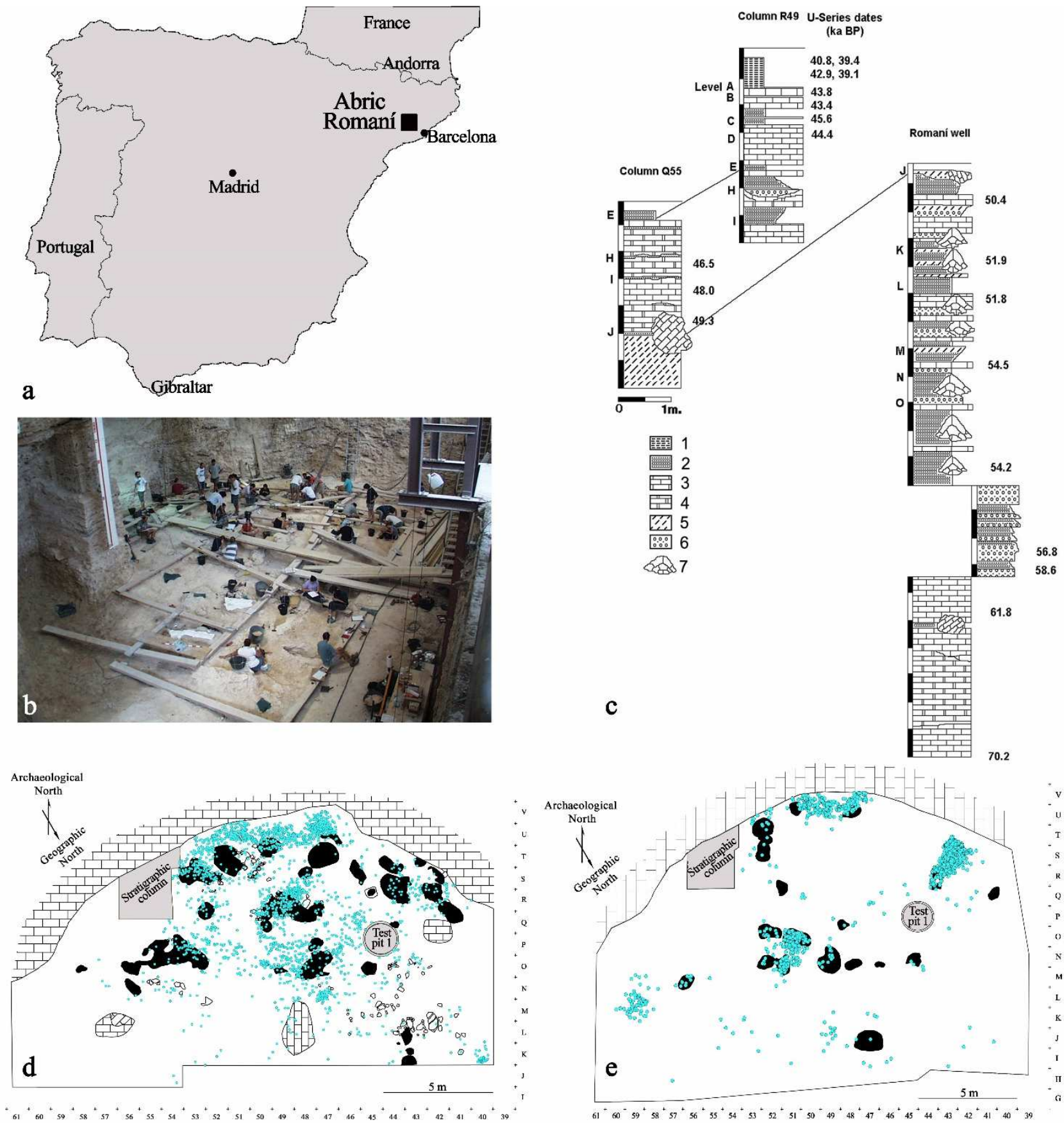
Figure 2 - Length-width ratio and thickness boxplots of cores-on-flakes and double ventral flakes in layers $\mathrm{M}$ and $\mathrm{L}$. Measures are expressed in millimetres.
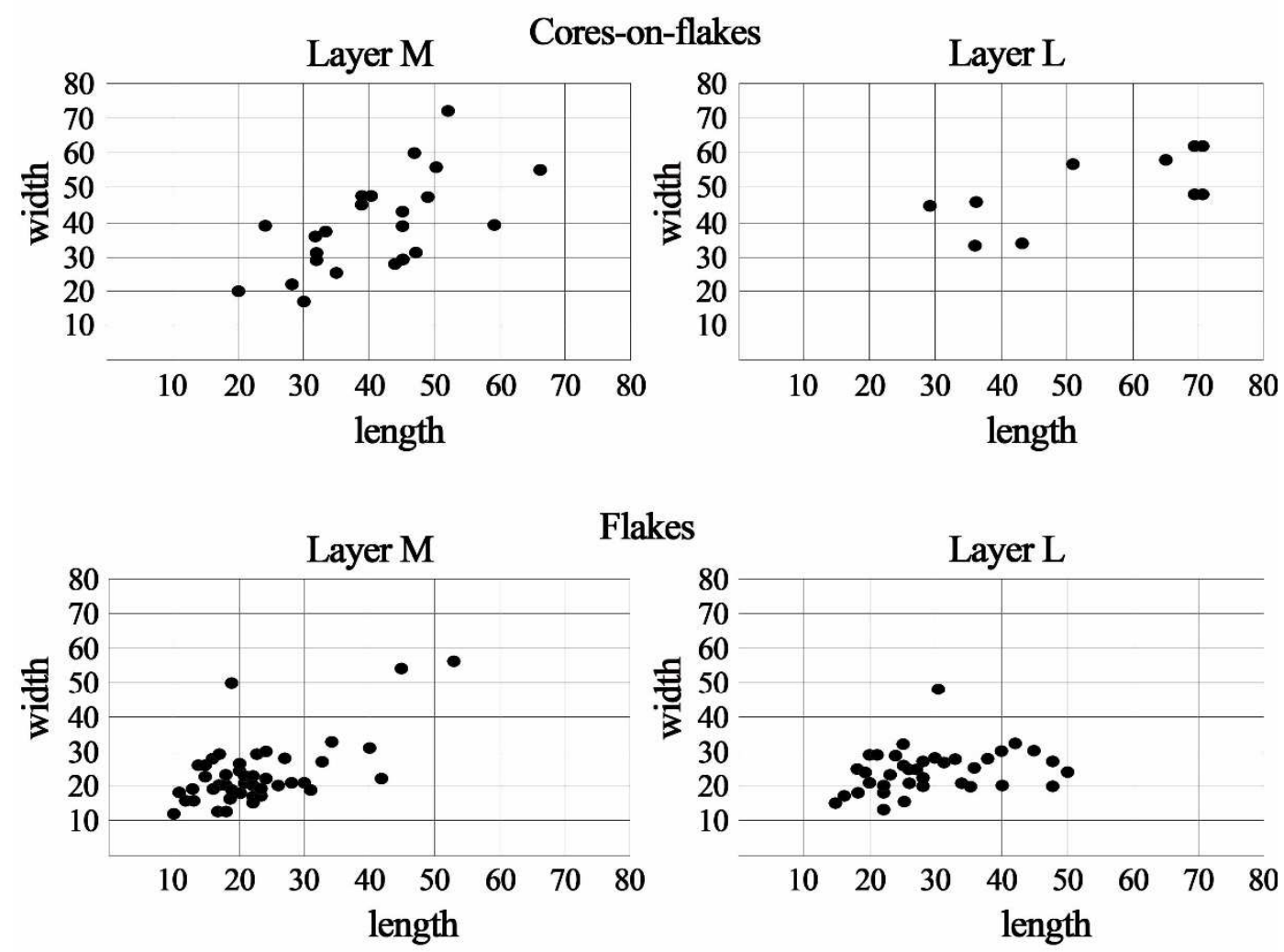

Flakes

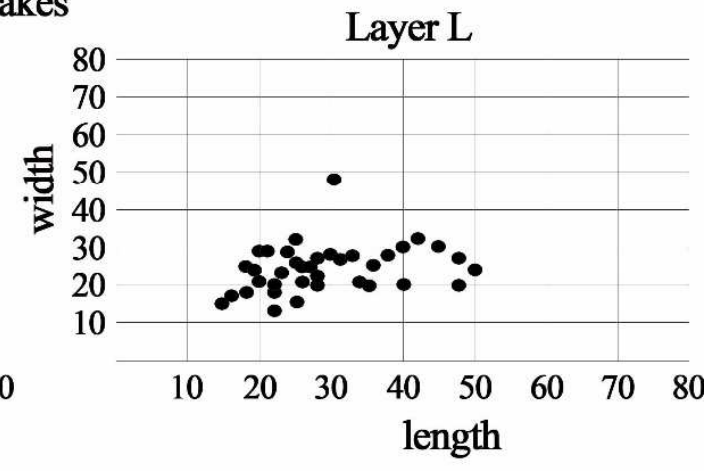

Cores-on-flakes

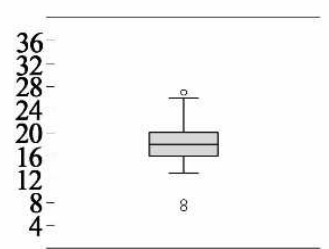

Layer M

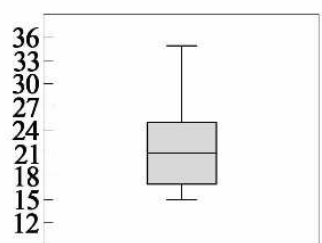

Layer L

thickness

Flakes

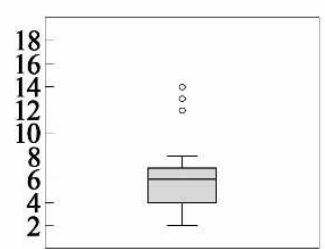

Layer M

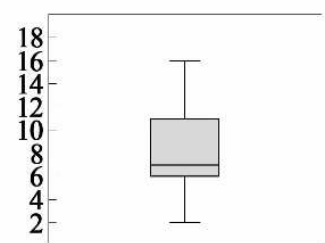

Layer L

thickness 
Figure 3 - Layer M. a. Refits in RMU flint-073. It was composed by 37 pieces; b-c. Cores-onflakes and their refitted products showing ramification along the exploitation of the block.

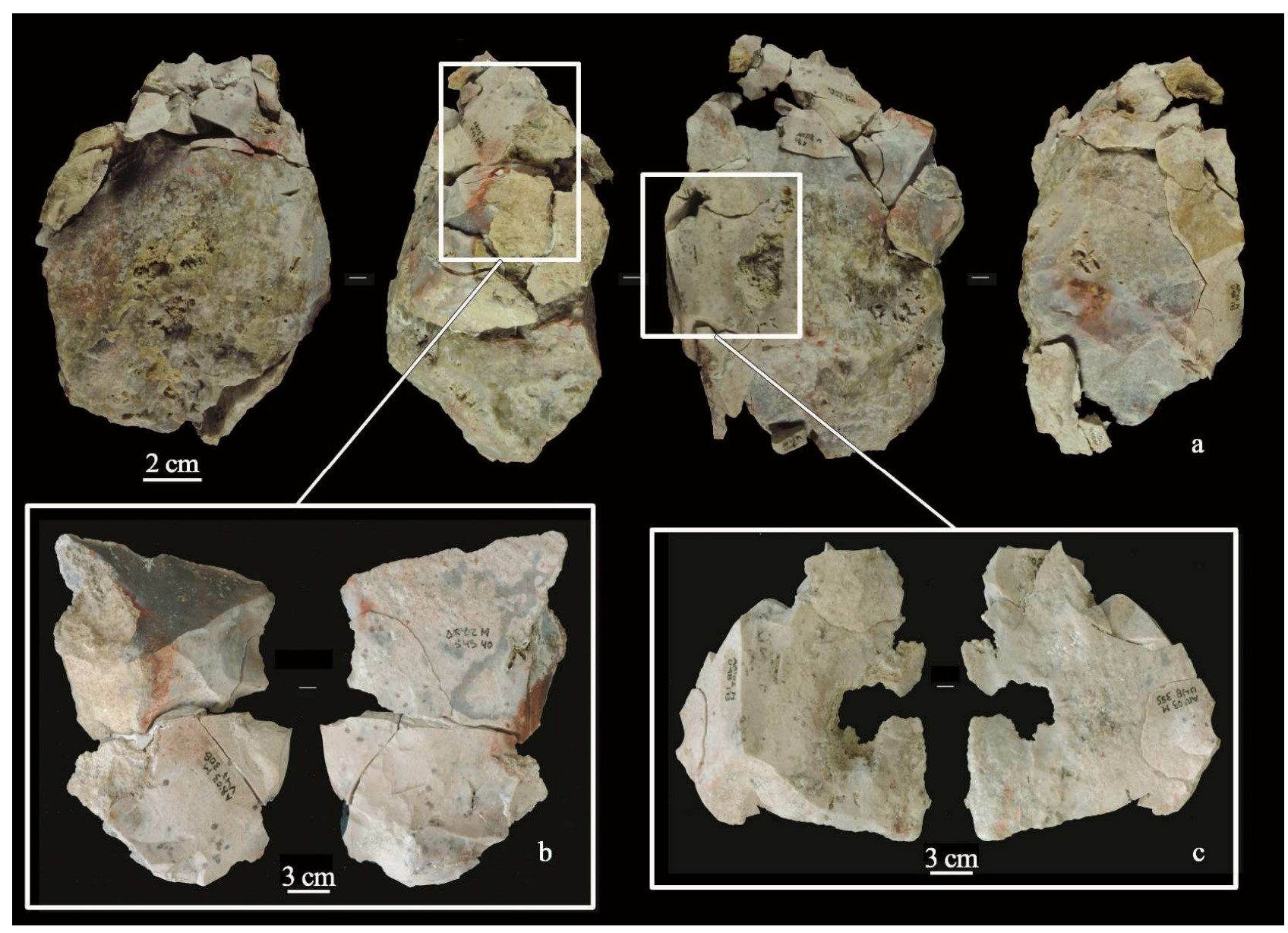


Figure 4 - Layer M. Picture of refits in RMU flint-075 and drawings of the five cores exploited within this block (a-e). Except core 'a', the others are cores-on-flakes obtained from blanks extracted with low knapping control due to the high inhomogeneity of the black. Letters near the drawings refer to the cores showed in the picture; f-h. Some of the products extracted. Drawing by F. Romagnoli.
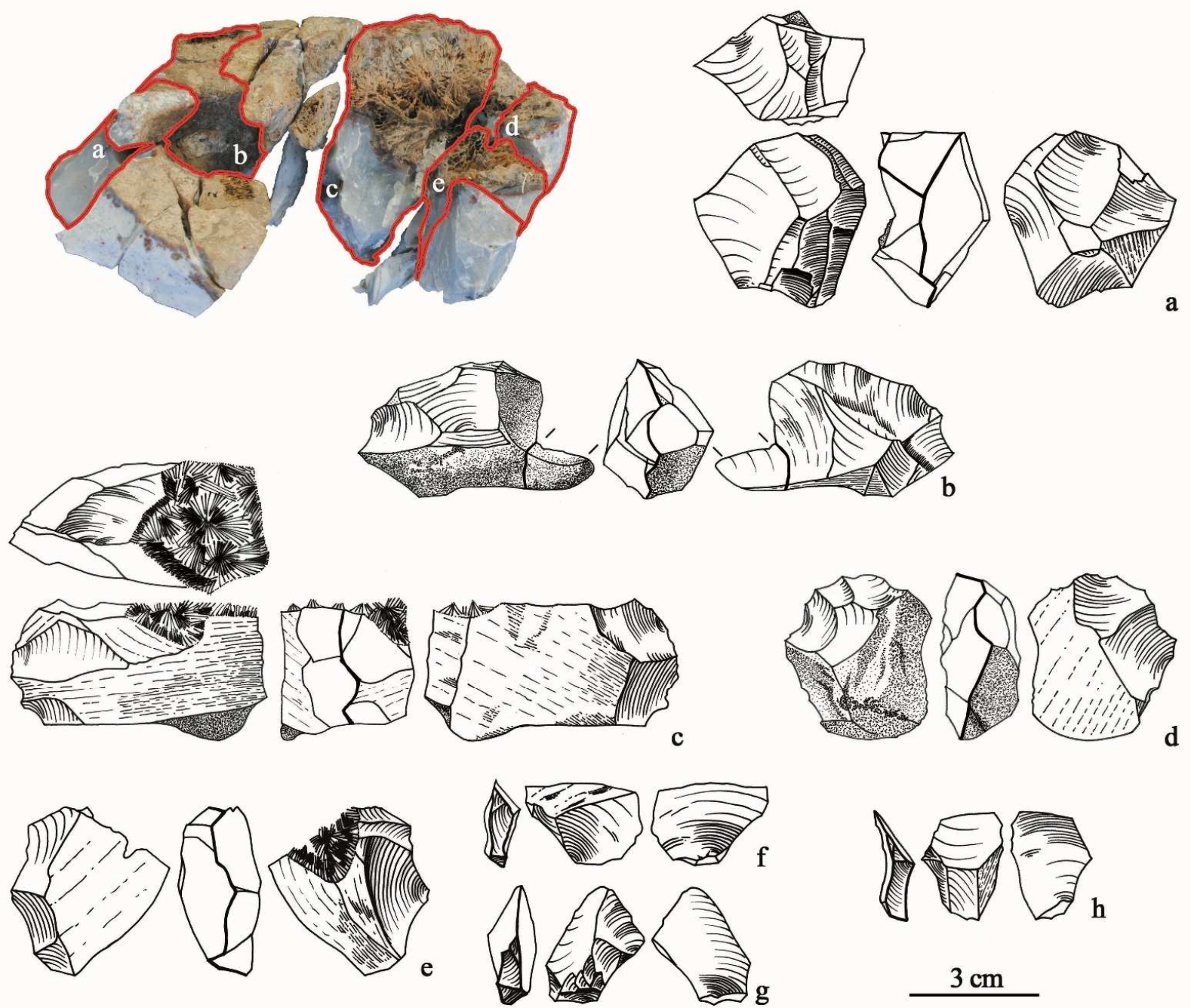
Figure 5 - Layer M. Spatial distribution of RMU flint-020 showing the spatial discontinuity in two ramification sequences: refit 6 (a) and refit 1 (b).

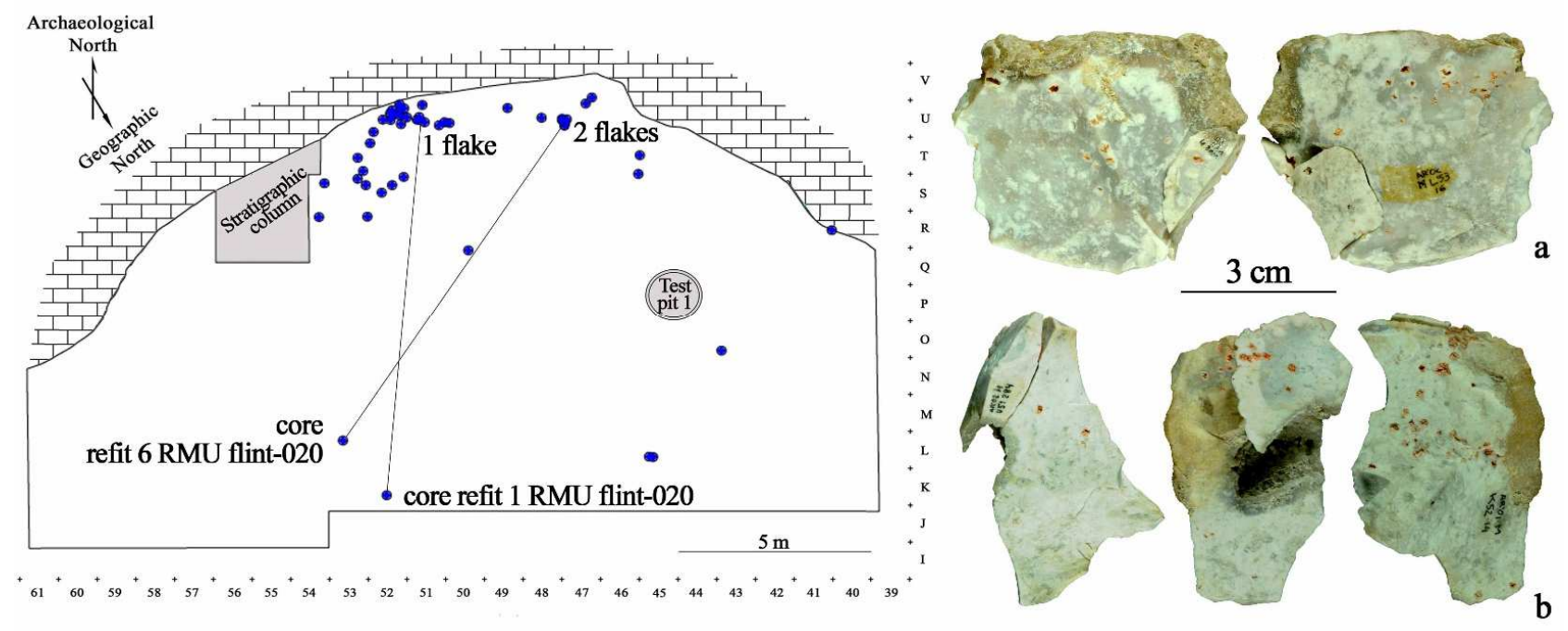

Figure 6 - Layer L. Diacritic lecture of two cores-on-flakes imported at the site as toolkits. Drawings F. Romagnoli.

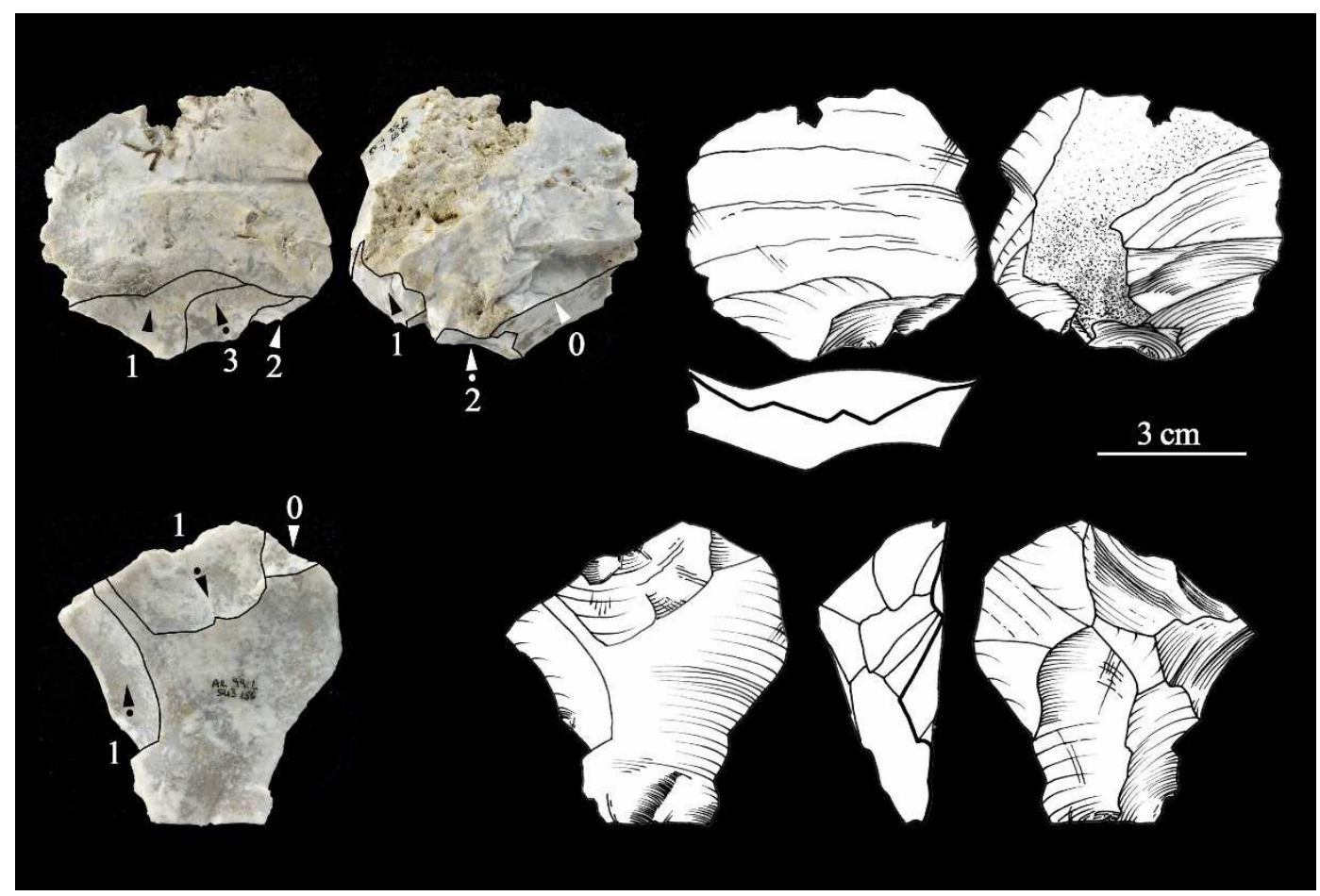


Figure 7 - Layer L. a. Refits in RMU flint-001 showing the exploitation as a core-on-flake of a large double-ventral flake imported at the site as toolkit; $b$. At the end of its use life the core-onflake was retouched on the left edge and manufactures as a denticulate scraper; c. Refits in RMU flint-016 showing the exploitation of a core-on-flake, which was extracted during the exploitation of a block at the site. It was the only case in which the 'ancestor' productive sequence of a core-onflake was attested at the site.

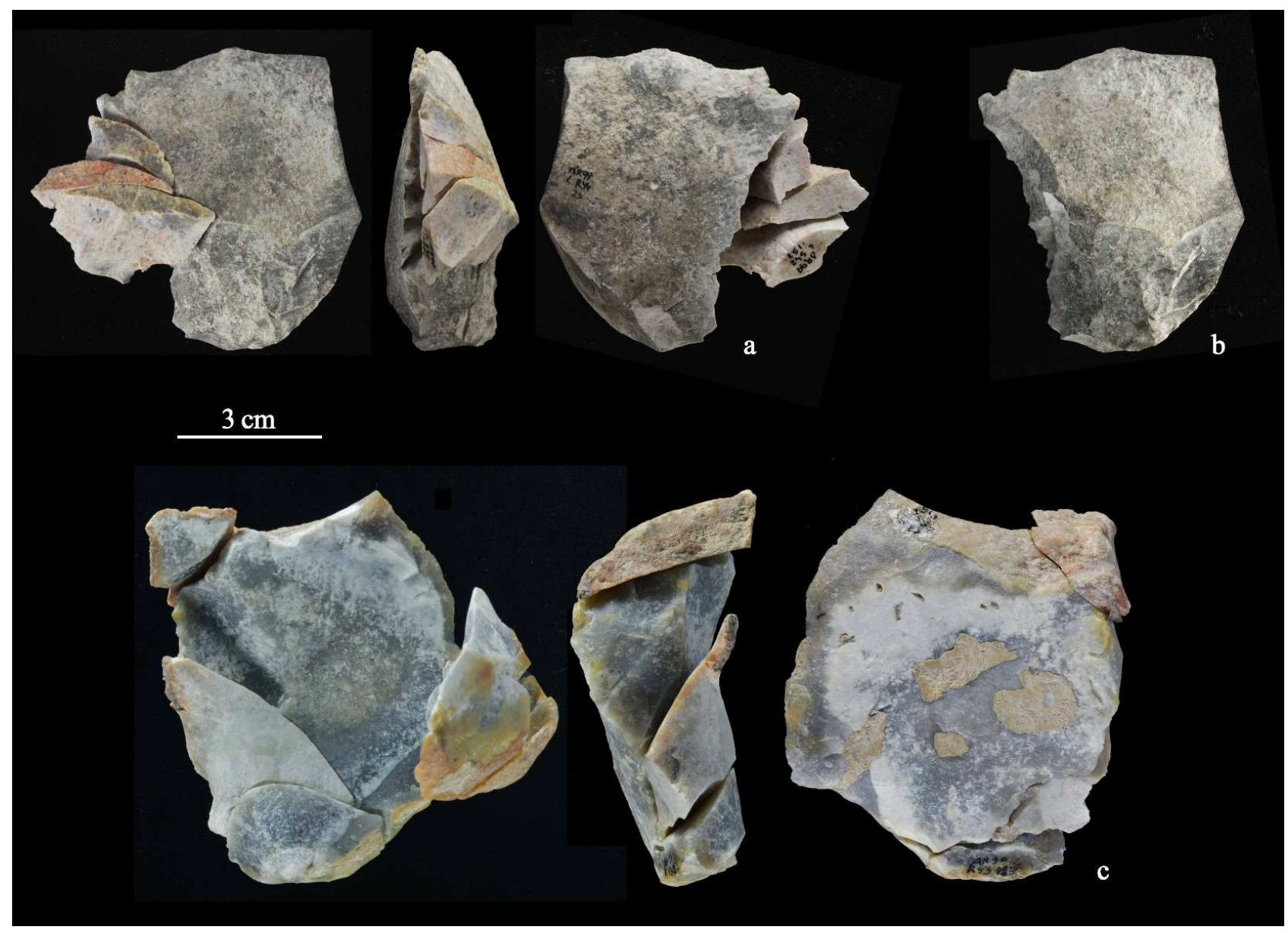



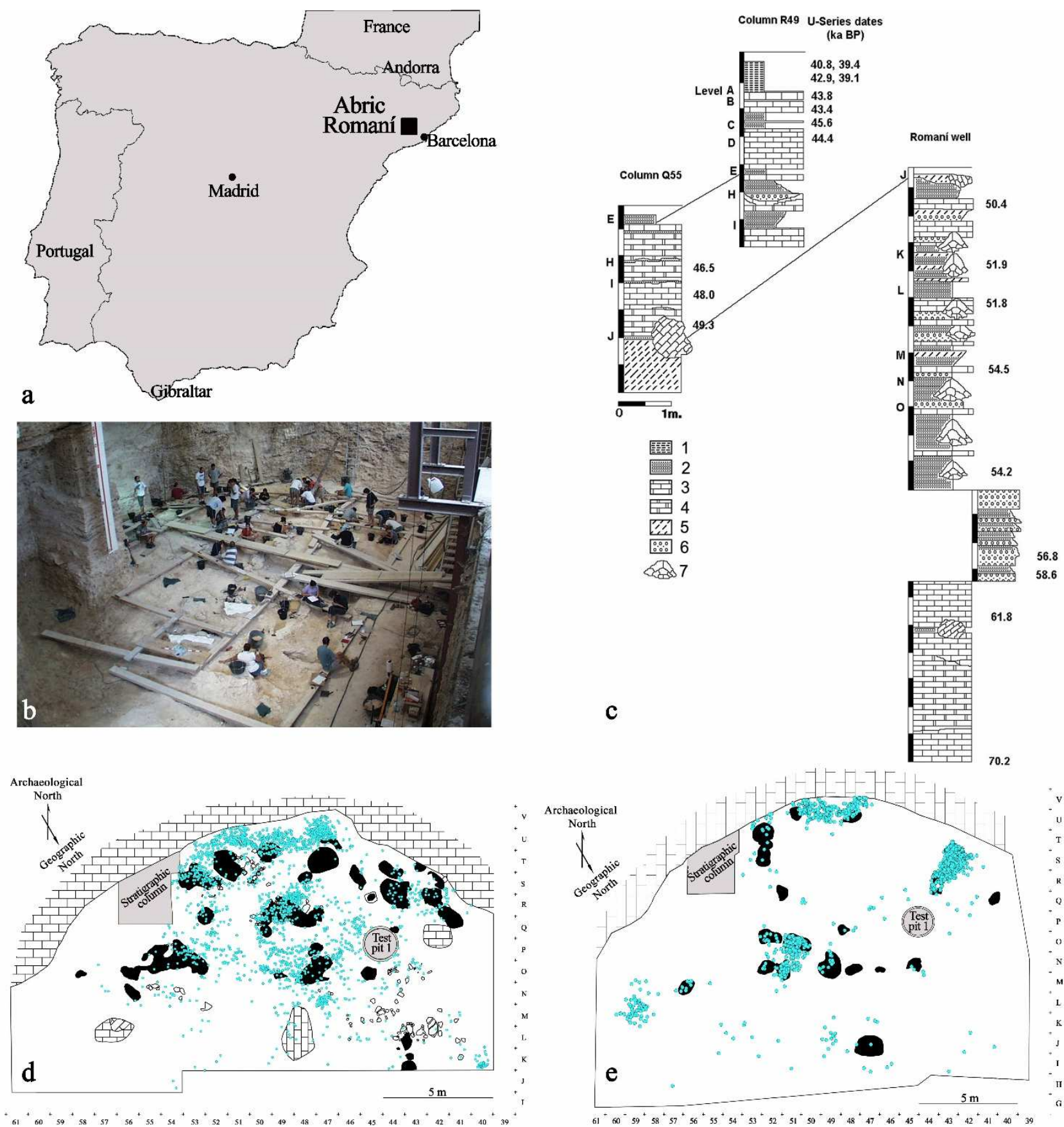